\title{
Compliance of Indoor Air Contaminants within the Main Prayer Halls of Mosques in Malacca with Malaysia's Indoor Air Quality Standard
}

\author{
Nur Baitul Izati Rasli', "Mohd Rodzi Ismail',2, Nor Azam Ramli', \\ Syabiha Shith', Amni Umirah Mohamad Nazir', Noor Faizah Fitri \\ Md Yusof ${ }^{1}$ and Nazatul Syadia Zainordin ${ }^{1,3}$
}

Published online: 31 December 2019

To cite this article: Nur Baitul Izati Rasli, Mohd Rodzi Ismail, Nor Azam Ramli, Syabiha Shith, Amni Umirah Mohamad Nazir, Noor Faizah Fitri Md Yusof and Nazatul Syadia Zainordin (2019). Compliance of indoor air contaminants within the main prayer halls of mosques in Malacca with Malaysia's indoor air quality standard. Journal of Construction in Developing Countries, 24(2): 105-121. https://doi.org/10.21315/jcdc2019.24.2.5.

To link to this article: https://doi.org/10.21315/jcdc2019.24.2.5

\begin{abstract}
This study examined the compliance of indoor air contaminants (total volatile organic compound [TVOC], ozone $\left[\mathrm{O}_{3}\right]$, carbon monoxide [CO], formaldehyde $\left[\mathrm{CH}_{2} \mathrm{O}\right]$, particulate matter $\left[\mathrm{PM}_{1}, \mathrm{PM}_{2.5}, \mathrm{PM}_{5}\right.$ and $\left.\mathrm{PM}_{10}\right]$ and carbon dioxide $\left.\left[\mathrm{CO}_{2}\right]\right)$ during Dhuhr/Friday and Asr prayers with the guideline limits in Malaysia's Industrial Code of Practice (ICOP). Monitoring was conducted from 12:00-5:00 p.m. in three prominent mosques in Malacca City, namely, M1 (a historic mosque; during Dhuhr at 1:07-1:18 p.m. to Asr at 4:31-4:42 p.m.), M2 (a historic mosque; during Friday at 1:38-1:48 p.m. to Asr at 4:33-4:50 p.m.) and M3 (a floating mosque on the Straits of Malacca; during Dhuhr at 1:12-1:27 p.m. to Asr at 4:33-4:50 p.m.). Results show that the mean concentrations of the nine indoor air contaminants in M1, M2 and M3 did not exceed ICOP's limits, except for the ozone concentration in M3 that exceeded the limit at $0.150 \mathrm{ppm}$. We conclude that the concentration levels of indoor air contaminants in the studied mosques are in compliance with Malaysia's ICOP and the non-compliance issue with regard to the ozone concentration in one of the mosques is due to the mosque's location in a busy coastal and marine area.
\end{abstract}

Keywords: Indoor air quality (IAQ), Mosque, Chemical air contaminant, Particulate matter, Ventilation performance indicator

\section{INTRODUCTION}

Mosques are a tourist attraction in Malacca and have been visited by locals and outsiders since Malacca was declared a heritage city in 2008. For Muslims, mosques represent places of great importance and are unique in their functions and operations. Worshipers or congregators need to feel comfortable, calm and peaceful during their prayers (salāh) or while performing other religious activities within the main prayer halls of mosques. The main prayer hall of a mosque is an indoor space accessible to Muslims and the public. The hall is occupied at least five times a day because Muslims commonly perform five compulsory prayers (salāh) daily. However, the prayer times and durations vary corresponding to areas, regions

\footnotetext{
'Environmental Assessment and Clean Air Research (EACAR), School of Civil Engineering, Engineering Campus, Universiti Sains Malaysia (USM), 14300 Nibong Tebal, Pulau Pinang, MALAYSIA

${ }^{2} S c h o o l$ of Housing Building and Planning, Universiti Sains Malaysia (USM), 11800 USM, Pulau Pinang, MALAYSIA ${ }^{3}$ Faculty of Environmental Studies, Universiti Putra Malaysia (UPM), 43400 UPM Serdang, Selangor Darul Ehsan, MALAYSIA

*Corresponding author: rodzi@usm.my
} 
and time zones. The Fajr (dawn) prayer time for Malaysia is from 6:00-7:00 a.m., the Dhuhr (after midday) prayer is from 1:00-2:00 p.m., the Asr (afternoon) prayer is from 4:30-5:30 p.m., the Maghrib (after sunset) prayer is from 7:00-8:00 p.m. and the Isha (evening) prayer is from 8:30-9:30 p.m. The main prayer halls of mosques are fully occupied on Fridays by worshippers as male adult Muslims congregate to listen to sermons and perform the Friday prayer from around 1:00-2:30 p.m. On this holy day, the Dhuhr prayer is replaced by the Friday prayer and the number of vehicles that transport the worshipers to the mosques increases. The indoor conditions of mosques should provide acceptable thermal comfort for worshipers to feel comfortable and calm and leave with a feeling of tranquility and peace (Abdullah, Majid and Othman, 2016). Given that mosques are consistently used by the public, their indoor air quality (IAQ) needs to be monitored because it is threatened by various contaminants from indoor and outdoor sources that considerably affect the indoor environment (Elbayoumi et al., 2014).

However, Lee and Chang (2000) reported that indoor pollutant levels could be greater than the outdoor pollutant levels. The factors that affect IAQ include lack of ventilation, poor outdoor air quality, existence of indoor contaminant sources, lack of maintenance, mechanical ventilation and air conditioning (MVAC) installation, water intrusion and resident activity (Fernández et al., 2013; Prihatmanti and Bahauddin, 2014). However, pollutants generated from sources within the indoor environment may lead to higher exposure to indoor air contaminant concentrations in comparison with the outdoors due to the lower air flow in the former. These sources include cleaning procedures, building materials, furniture, furnishing, use of chemical products and general activities.

Several studies in Malaysia have shown that thermal comfort, sick building syndrome (SBS) and displeasure in buildings have become common issues (Amin, Akasah and Razzaly, 2015; Shan et al., 2016). Inadequate ventilation rates and high concentrations of $\mathrm{CO}_{2}, \mathrm{PM}_{2.5}$ and biological pollutants have been observed in mosque buildings in Turkey and the Kingdom of Saudi Arabia (Ocak et al., 2012; Hameed and Habeeballah, 2013). Malaysia's Industrial Code of Practice (ICOP) was established to ensure that employees and occupants are protected from poor IAQ that can adversely affect human health, well-being and productivity (Department of Occupational Safety and Health [DOSH], 2010).

The objective of this study was to assess the level of compliance to the guideline limit in ICOP of nine indoor air contaminants, namely, total volatile organic compound (TVOC), ozone $\left(\mathrm{O}_{3}\right)$, carbon monoxide $(\mathrm{CO})$, formaldehyde $\left(\mathrm{CH}_{2} \mathrm{O}\right)$, particulate matter $\left(\mathrm{PM}_{1}, \mathrm{PM}_{2.5}, \mathrm{PM}_{5}\right.$ and $\left.\mathrm{PM}_{10}\right)$ and carbon dioxide $\left(\mathrm{CO}_{2}\right)$, during Dhuhr/Friday and Asr prayer times in the main prayer halls of mosques.

\section{MATERIAL AND METHOD}

\section{Sampling Locations}

This research was conducted in the main prayer halls of three prominent mosques (coded as M1, M2 and M3) in Malacca City. M1 and M2 are historical mosques located in the centre of Malacca City and $M 3$ is a floating mosque located on the man-made Malacca Island and built on stilts above the Straits of Malacca. According to the Malaysian Standard: Architecture and Asset Management of Masjid - Code of Practice (MS 2577: 2014) (MS, 2014), the designs of M1 and M2 are 
influenced by mosques in Southeast Asia (pyramid-shaped roof) and the design of M3 is influenced by mosques in Turkey (Ottoman style). Figure 1 shows a view of the studied mosques and their respective coordinates.

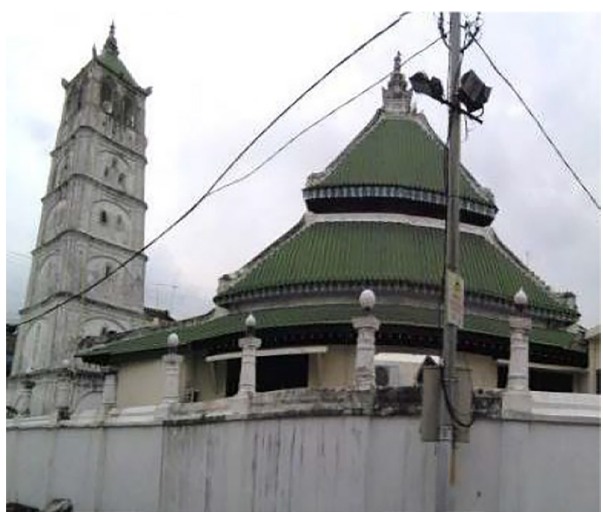

$\mathrm{M} 1$

(N2.196674, E102.247285)

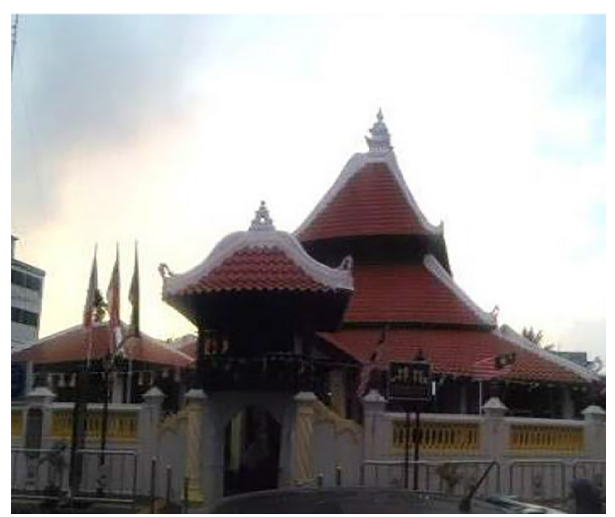

M2

(N2.199205, E102.247514)

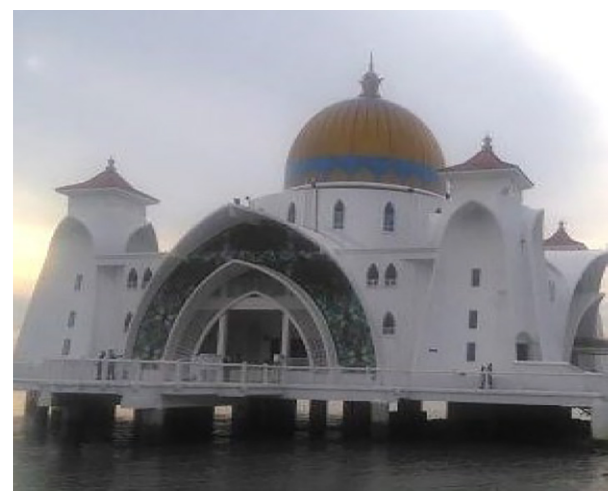

M3

(N2.179007, E102.248871)

Figure 1. View of the Studied Mosques and Their Coordinates

\section{Selection of Monitoring Instruments}

An IAQ probe (IQ-610) was used to measure TVOC, $\mathrm{O}_{3}, \mathrm{CO}$ and $\mathrm{CO}_{2}$ and a formaldehyde multi-mode monitor (FM-801) was utilised to measure $\mathrm{CH}_{2} \mathrm{O}$. Both instruments are of the Graywolf model. In addition, an airborne particle counter (Handheld 3016 IAQ) of the Lighthouse model was used to measure PM $, \mathrm{PM}_{2.5}, \mathrm{PM}_{5}$ and $P M_{10}$. All instruments were mounted on a tripod at $1.3 \mathrm{~m}$ above the ground at one sampling point and placed at the main prayer hall. The details of the measurement instruments are shown in Table 1. The total main prayer hall areas of M1, M2 and M3 are $216.579 \mathrm{~m}^{2}(\mathrm{~W}: 13.521 \mathrm{~m} \times \mathrm{L}: 16.018 \mathrm{~m}), 151.388 \mathrm{~m}^{2}(\mathrm{~W}: 12.286 \mathrm{~m}$ $\times \mathrm{L}: 12.322 \mathrm{~m})$ and $635.370 \mathrm{~m}^{2}(\mathrm{~W}: 25.358 \mathrm{~m} \times \mathrm{L}: 25.056 \mathrm{~m})$, respectively. 
Nur Baitul Izati Rasli et al.

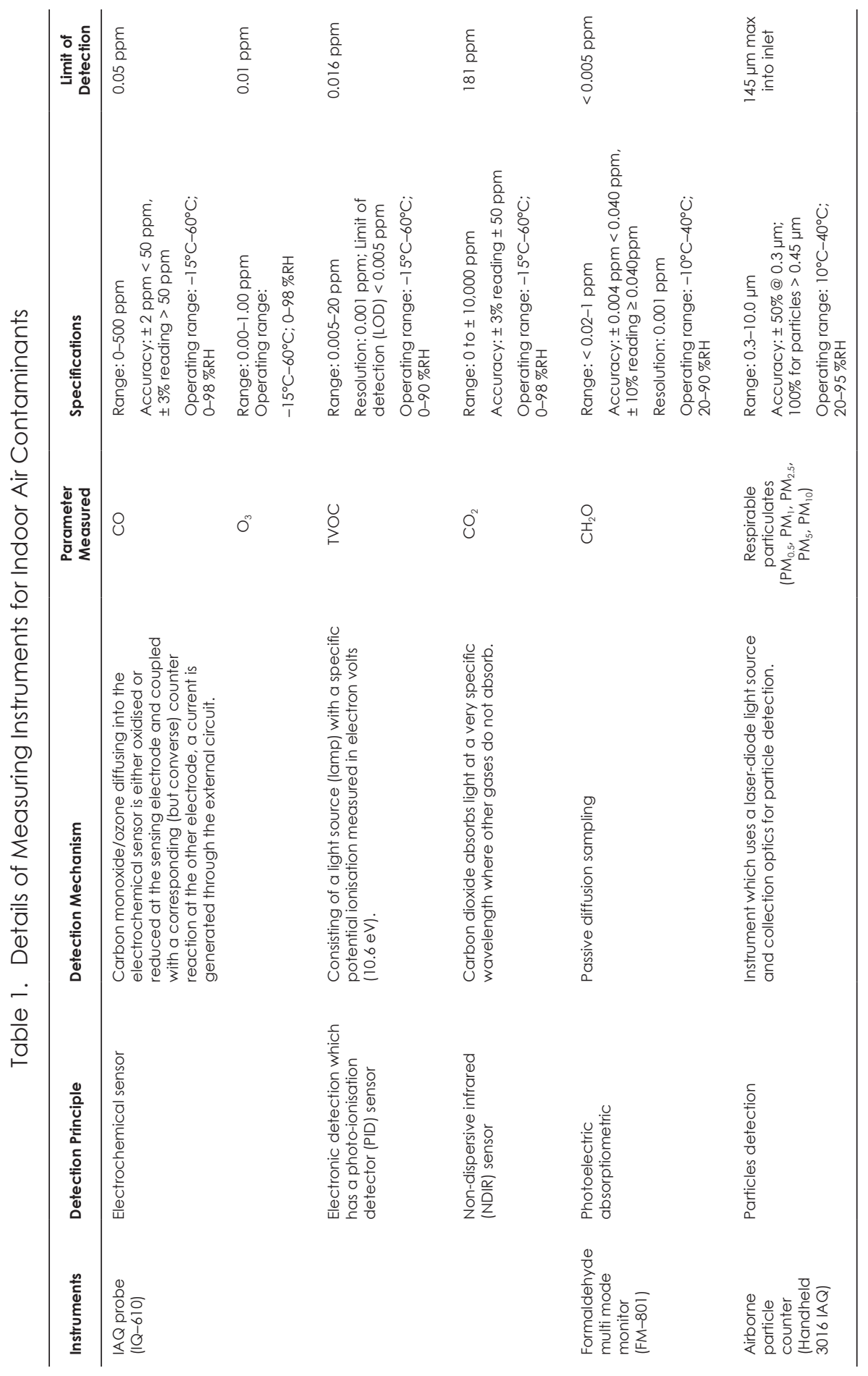




\section{Sampling Method}

The sampling events in the mosques were conducted for five hours from 12:005:00 p.m. The sampling was performed for three days, with one day for each mosque with a carpeted floor. Table 2 summarises the sampling work performed in the three mosques. All of the mosques rely on passive ventilation (i.e. windows and doors) and active ventilation (i.e. fans) systems during prayer time. The doors and windows were kept open during the monitoring period and the fans were switched on during the prayer times only.

The quality assurance and quality control (QA/QC) for Graywolf and Lighthouse models was performed by annual factory calibration. All instruments were attached together and the output parameters were displayed on a setup screen. Readings of all the parameters were obtained after 30 minutes to one hour to stabilise. Then, the location was set according to the current time and date of monitoring and the data were set to one-minute real-time average $1100 \%$ data logging). The instruments were placed at the centre of the main prayer hall and the selected sampling location was at least $0.5 \mathrm{~m}$ from the walls, corners and windows but not directly in front of air-conditioning system units and floor fans and not within $2 \mathrm{~m}$ of the doors.

Table 2. Sampling Schedule and Activities

\begin{tabular}{|c|c|c|c|c|}
\hline Mosque & Session & Prayer Time & $\begin{array}{l}\text { Monitoring Activities } \\
\text { (Within Five Hours of } \\
\text { Sampling Period) }\end{array}$ & $\begin{array}{l}\text { Parameters } \\
\text { Monitored }\end{array}$ \\
\hline M1 & $\begin{array}{l}\text { Dhuhr to } \\
\text { Asr prayer }\end{array}$ & $\begin{array}{l}\text { 1:07-1:18 p.m. } \\
\text { 4:31-4:42 p.m. }\end{array}$ & \multirow{3}{*}{$\begin{array}{l}\text { 1. Before Dhuhr/Friday } \\
\text { prayer } \\
\text { 2. During Dhuhr/Friday } \\
\text { prayer } \\
\text { 3. Between Dhuhr/Friday } \\
\text { and Asr prayer } \\
\text { 4. During Asr prayer }\end{array}$} & \multirow{3}{*}{$\begin{array}{l}\text { TVOC, } \mathrm{O}_{3}, \mathrm{CO}, \\
\mathrm{CH}_{2} \mathrm{O}, \mathrm{PM}_{1}, \\
\mathrm{PM}_{2.5}, \mathrm{PM}_{5,} \\
\mathrm{PM}_{10} \text {, and } \mathrm{CO}_{2}\end{array}$} \\
\hline M2 & $\begin{array}{l}\text { Friday to } \\
\text { Asr prayer }\end{array}$ & $\begin{array}{l}\text { 1:38-1:48 p.m. } \\
\text { 4:33-4:50 p.m. }\end{array}$ & & \\
\hline M3 & $\begin{array}{l}\text { Dhuhr to } \\
\text { Asr prayer }\end{array}$ & $\begin{array}{l}\text { 1:12-1:27 p.m. } \\
\text { 4:33-4:50 p.m. }\end{array}$ & & \\
\hline
\end{tabular}

\section{RESULTS AND DISCUSSIONS}

The indoor air contaminants were divided into chemical air contaminants (TVOC, $\mathrm{O}_{3}, \mathrm{CO}$ and $\left.\mathrm{CH}_{2} \mathrm{O}\right)$, respirable particulate matter $\left(\mathrm{PM}_{1}, \mathrm{PM}_{2.5}, \mathrm{PM}_{5}\right.$ and $\left.\mathrm{PM}_{10}\right)$ and ventilation performance indicator $\left(\mathrm{CO}_{2}\right)$. Figures 2-4 show the concentrations of these contaminants in M1, M2 and M3, respectively. The results show fluctuations in the concentration of chemical air contaminants in M1, M2 and M3 during prayer and non-prayer times, except for the ozone concentrations in M1 and M2. The results also indicate that $\mathrm{PM}_{10}$ was the dominant respirable PM in the three mosques. The concentrations of the ventilation performance indicator were higher in the mosques during prayer times than during non-prayer times. Tables $3-5$ show the concentration levels of indoor air contaminants in comparison with the acceptable guideline limit recommended by ICOP for the studied mosques. 


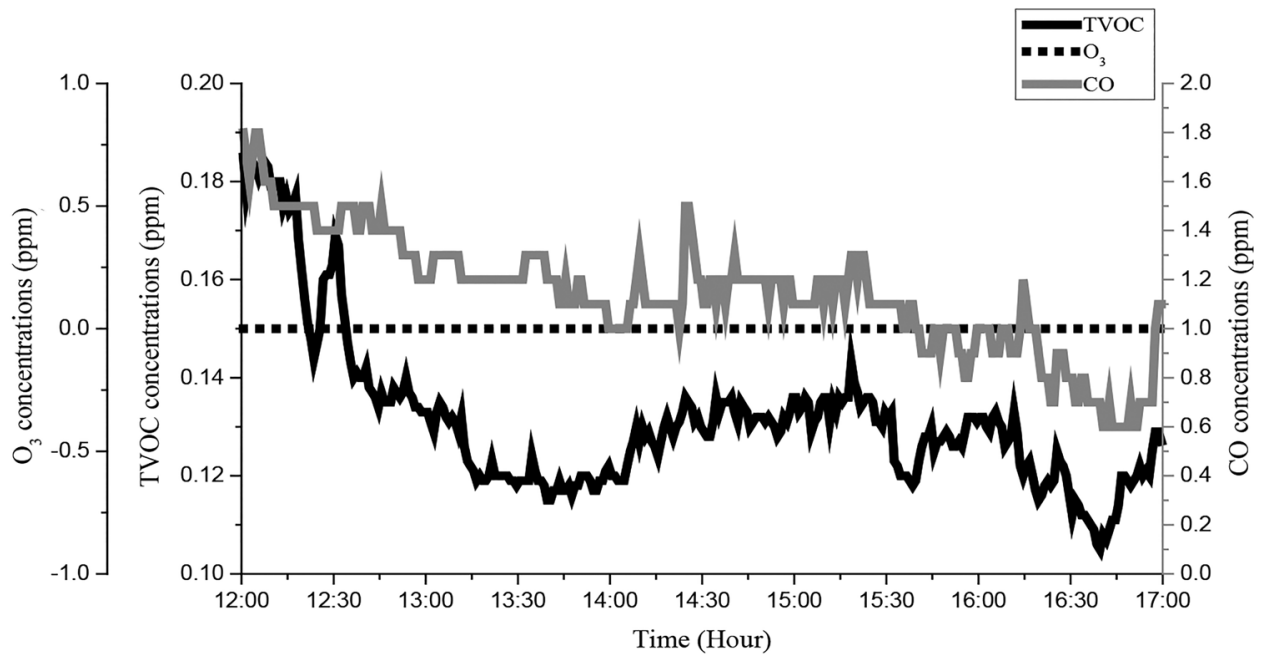

(a) Chemical Air Contaminants (TVOC, $\left.\mathrm{O}_{3}, \mathrm{CO}\right)\left({ }^{*} \mathrm{CH}_{2} \mathrm{O}\right.$ not detected)

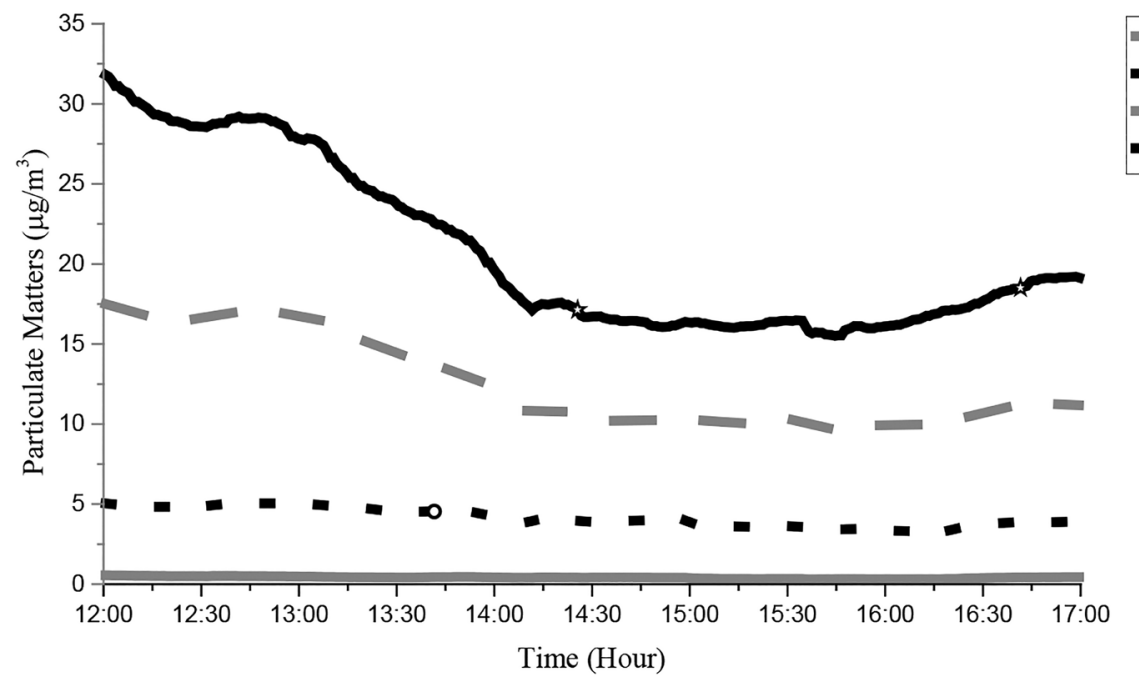

(b) Respirable Particulate Matter $\left(\mathrm{PM}_{1}, \mathrm{PM}_{2.5}, \mathrm{PM}_{5}, \mathrm{PM}_{10}\right)$

Figure 2. Concentrations of the Indoor Air Contaminants during Dhuhr to Asr Prayer Times at M1 


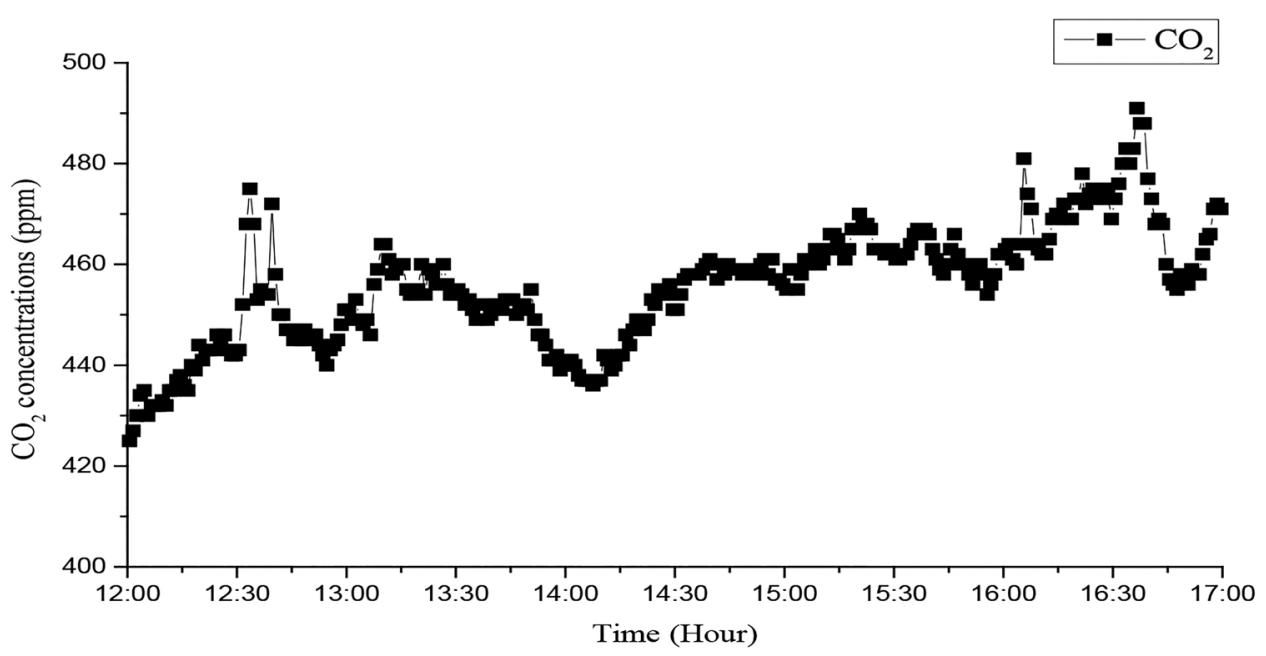

(c) Ventilation Performance Indicator $\left(\mathrm{CO}_{2}\right)$

Figure 2. (continued)

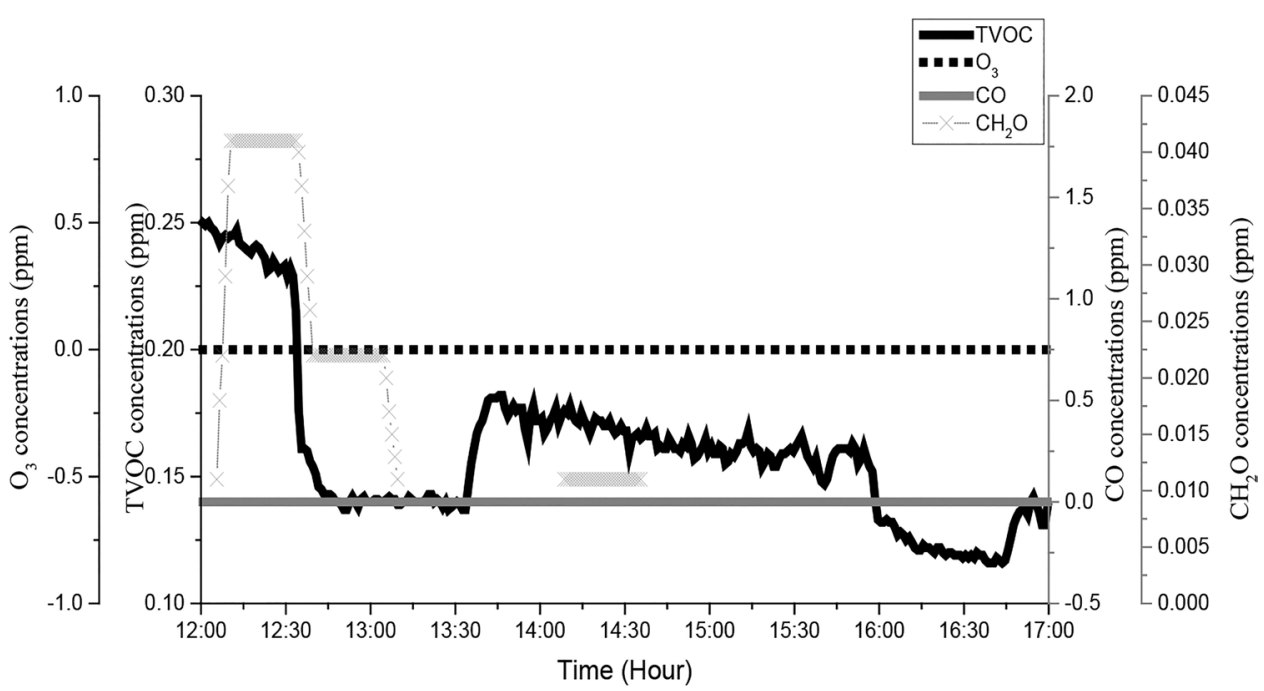

(a) Chemical Air Contaminants (TVOC, $\mathrm{O}_{3}, \mathrm{CO}, \mathrm{CH}_{2} \mathrm{O}$ )

Figure 3. Concentrations of the Indoor Air Contaminants during Jumaat to Asr Prayer Times at M2 


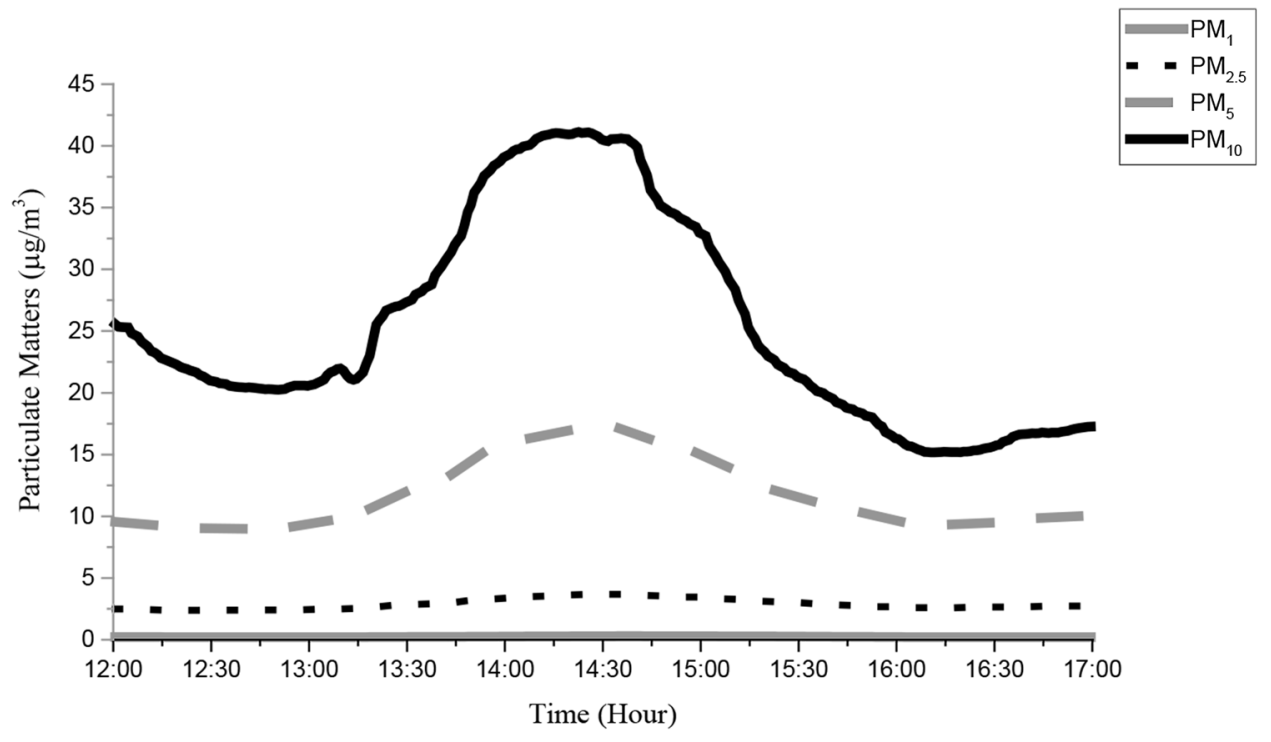

(b) Respirable Particulate Matter $\left(\mathrm{PM}_{1}, \mathrm{PM}_{2.5}, \mathrm{PM}_{5}, \mathrm{PM}_{10}\right)$

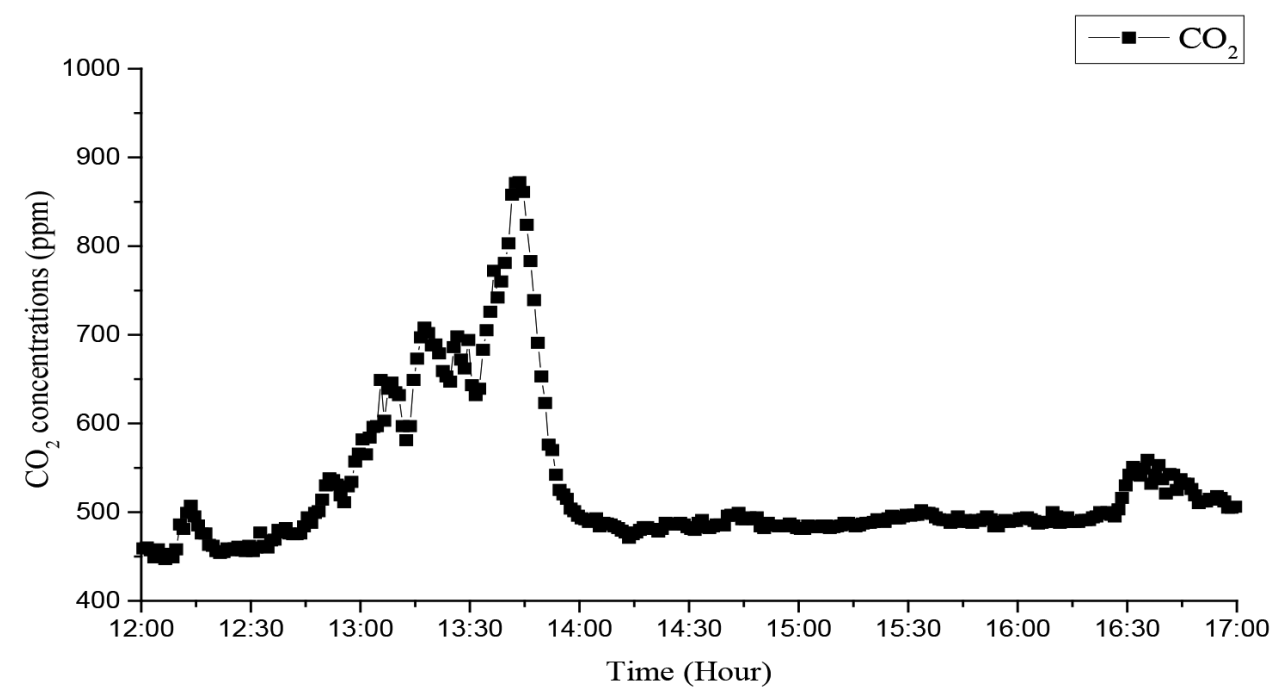

(c) Ventilation Performance Indicator $\left(\mathrm{CO}_{2}\right)$

Figure 3. (continued) 


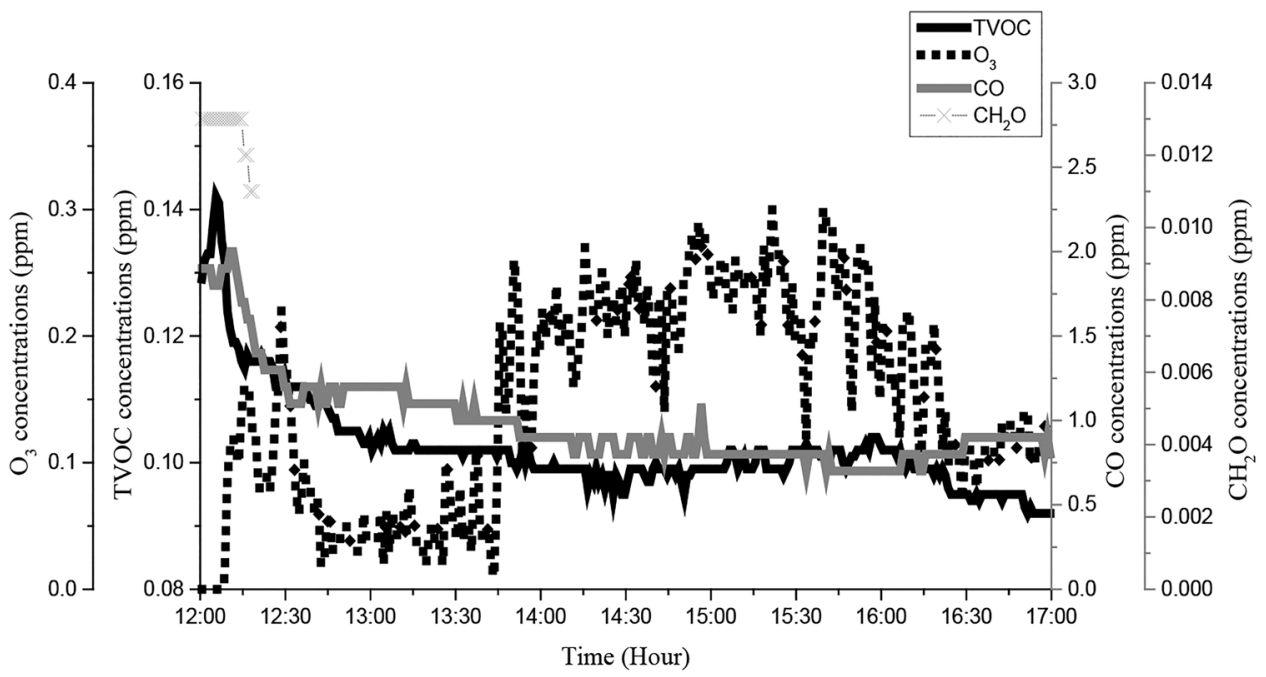

(a) Chemical Air Contaminants (TVOC, $\mathrm{O}_{3}, \mathrm{CO}, \mathrm{CH}_{2} \mathrm{O}$ )

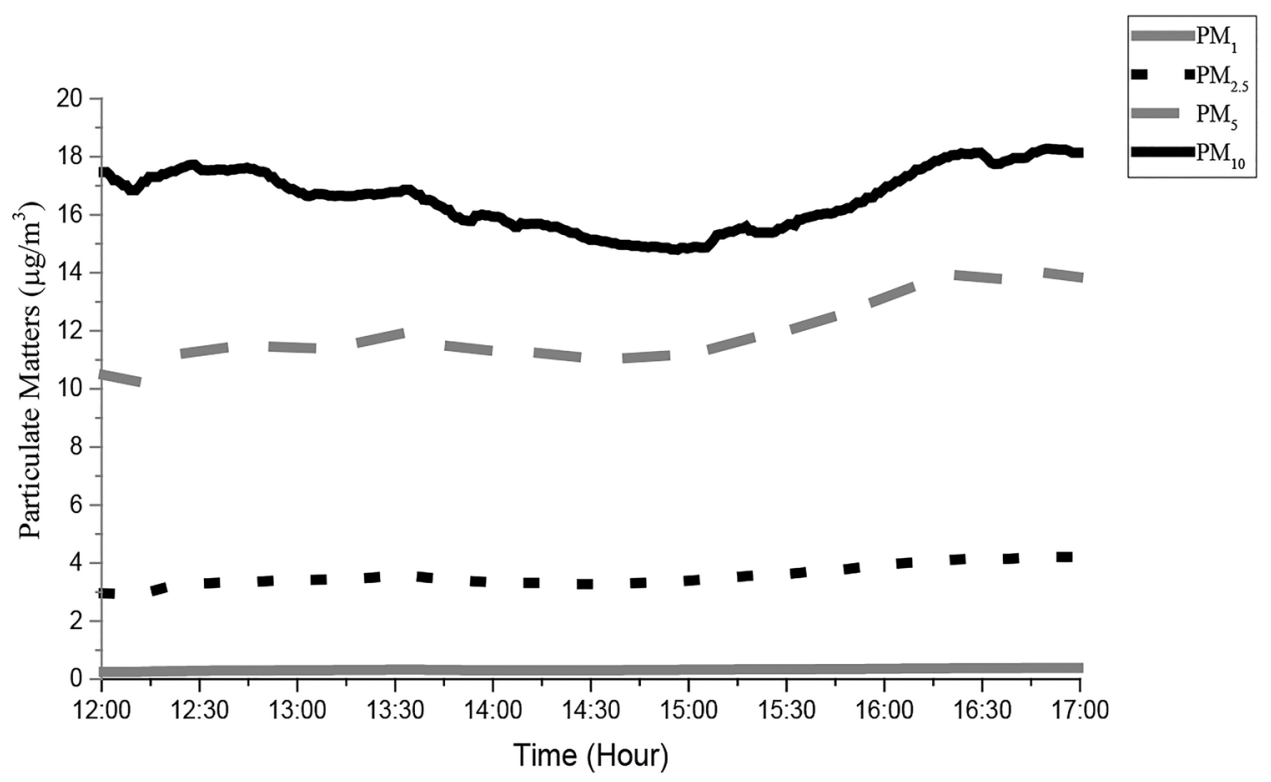

(b) Respirable Particulate Matter $\left(\mathrm{PM}_{1}, \mathrm{PM}_{2.5}, \mathrm{PM}_{5}, \mathrm{PM}_{10}\right)$

Figure 4. Concentrations of the Indoor Air Contaminants during Dhuhr to Asr Prayer Times at M3 


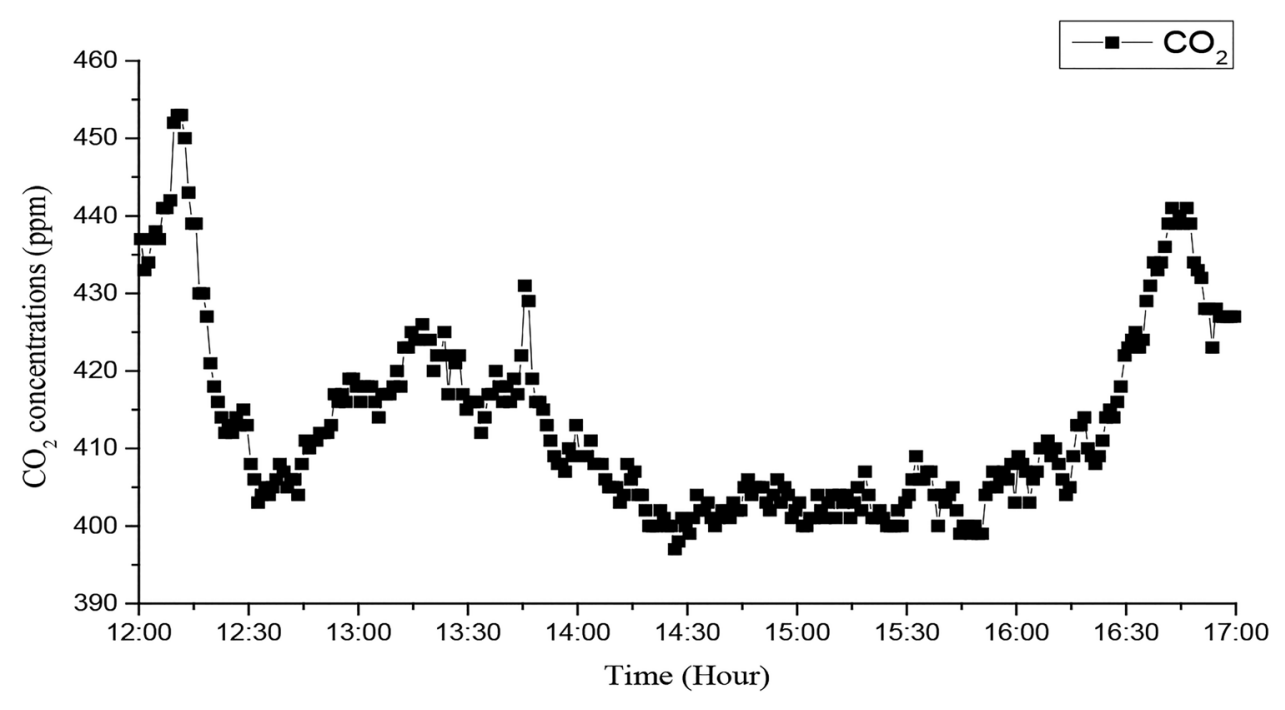

(c) Ventilation Performance Indicator $\left(\mathrm{CO}_{2}\right)$

Figure 4. (continued)

The results in Table 3 suggest that the mean TVOC concentration in M1 was slightly higher than that in $M 2$ and M3. The mean TVOC concentrations in M1, M2 and M3 were $0.132 \pm 0.016$ ppm (range: $0.105-0.185$ ppm), $0.129 \pm$ 0.008 ppm (range: $0.114-0.158$ ppm) and $0.102 \pm 0.008$ ppm (range: $0.092-0.142$ ppm), respectively. The mean of TVOC concentrations in M1, M2 and M3 were much smaller than the acceptable guideline limit of 3 ppm recommended by ICOP. TVOC concentrations in mosques can be influenced by the building materials and carpets used as floor covering in the mosques. As mentioned by Jokl (2000), volatile organic compounds (VOCs) can be produced by building materials and fittings, especially carpets and other floor covering materials. The concentrations of VOCs, including benzene, tolvene and chlorofluorocarbons (Environmental Protection Agency, 2012), can also be affected by temperature, humidity, seasons and other environmental factors (Jo and Sohn, 2009).

Meanwhile, the results suggest that the mean $\mathrm{O}_{3}$ concentration in $\mathrm{M} 3$ is higher than that in $\mathrm{Ml}$ and $\mathrm{M} 2$. The mean $\mathrm{O}_{3}$ concentration in $\mathrm{M} 3$ is $0.15 \pm 0.08 \mathrm{ppm}$ (range: 0-0.30 ppm) and exceeds the acceptable limit of 0.05 ppm recommended by ICOP. The high concentration of $\mathrm{O}_{3}$ in $\mathrm{M} 3$ may be due to the mosque's location in a coastal and marine area. This finding is in accordance with those of Tong et al. (2017) and Yahaya et al. (2017), who found that coastal and marine areas are the main sources of $\mathrm{O}_{3}$ concentrations due to the influenced of two factors, namely, site location and provincial transport. In these areas, during daytime, sea breeze from the sea to land and land breeze from the land to sea during night time bring new chemical mixtures of the ozone precursor, such as NOx and sea salt aerosol, that produce nitryl chloride at night and increase the ozone concentrations the next morning. McKendry and Lundgren (2000) also found that surface $\mathrm{O}_{3}$ is generally created by the reaction of anabatic winds and sea breeze formation with 
convective venting processes. However, the mean $\mathrm{O}_{3}$ concentration in $\mathrm{Ml}$ and M2 was $0.00 \pm 0.00$ ppm, which implies that no trace of $\mathrm{O}_{3}$ was present in the two mosques due to the absence of outgassed precursors. $\mathrm{O}_{3}$ is a secondary pollutant that can be influenced by precursor availability, local meteorology, seasonal variability (Lin et al., 2015; Awang et al., 2018), local sources and background hemispheric concentrations through transboundary transport (Ryoo et al., 2017).

Table 3. Descriptive Statistics of the Chemical Contaminants Concentrations

\begin{tabular}{|c|c|c|c|c|}
\hline Mosque & M1 & M2 & M3 & Acceptable Limit \\
\hline \multicolumn{4}{|c|}{ TVOC concentrations (ppm) } & $3 \mathrm{ppm}$ \\
\hline$N$ total & 300 & 300 & 300 & \\
\hline Mean \pm SD & $0.132 \pm 0.016$ & $0.129 \pm 0.008$ & $0.102 \pm 0.008$ & \\
\hline Minimum & 0.105 & 0.114 & 0.092 & \\
\hline Median & 0.130 & 0.128 & 0.101 & \\
\hline Maximum & 0.185 & 0.158 & 0.142 & \\
\hline \multicolumn{4}{|c|}{$\mathrm{O}_{3}$ concentrations (ppm) } & $0.05 \mathrm{ppm}$ \\
\hline$N$ total & 300 & 300 & 300 & \\
\hline Mean \pm SD & $0.00 \pm 0.00$ & $0.00 \pm 0.00$ & $0.15 \pm 0.08$ & \\
\hline Minimum & - & - & 0.00 & \\
\hline Median & - & - & 0.15 & \\
\hline Maximum & - & - & 0.30 & \\
\hline \multicolumn{4}{|c|}{ CO concentrations (ppm) } & 10 ppm \\
\hline$N$ total & 300 & 300 & 300 & \\
\hline Mean \pm SD & $1.14 \pm 0.24$ & $1.88 \pm 0.31$ & $0.98 \pm 0.27$ & \\
\hline Minimum & 0.60 & 1.30 & 0.70 & \\
\hline Median & 1.20 & 1.80 & 0.90 & \\
\hline Maximum & 1.80 & 2.50 & 2.00 & \\
\hline \multicolumn{4}{|c|}{$\mathrm{CH}_{2} \mathrm{O}$ concentrations (ppm) } & $0.1 \mathrm{ppm}$ \\
\hline$N$ total & - & 0.066 & 0.019 & \\
\hline Mean \pm SD & - & $0.024 \pm 0.004$ & $0.013 \pm 0.0006$ & \\
\hline Minimum & - & 0.011 & 0.011 & \\
\hline Median & - & 0.022 & 0.013 & \\
\hline Maximum & - & 0.029 & 0.013 & \\
\hline
\end{tabular}

The results also suggest that although the mean $\mathrm{CO}$ concentration in $M 2$ is slightly higher than that in $M 1$ and $M 3$, the mean $C O$ concentrations in all three mosques did not exceed the acceptable guideline limit value of $10 \mathrm{ppm}$ recommended by ICOP. The mean CO concentrations in M1, M2 and M3 were $1.14 \pm 0.24 \mathrm{ppm}$ (range: $0.60-1.80 \mathrm{ppm}), 1.88 \pm 0.31 \mathrm{ppm}$ (range: 1.30-2.50 ppm) and $0.98 \pm 0.27$ ppm (range: $0.70-2.00$ ppm), respectively. The contributions of CO concentrations may be due to the automobile exhaust from high traffic near the 
mosques and continuous $\mathrm{CO}$ concentrations can cause health issues among the occupants, especially children. For example, Evans et al. (2014) found that the risk of asthma in urban children can be aggravated by $\mathrm{CO}$ concentrations.

The highest mean $\mathrm{CH}_{2} \mathrm{O}$ concentration was observed in $\mathrm{M} 2$, followed by $\mathrm{M} 3$ and $\mathrm{M} 1$. The mean $\mathrm{CH}_{2} \mathrm{O}$ concentrations in $\mathrm{M} 2$ and $\mathrm{M} 3$ were $0.024 \pm$ 0.004 ppm (range: $0.011-0.029 \mathrm{ppm}$ ) and $0.013 \pm 0.0006 \mathrm{ppm}$ (range: $0.011-$ $0.013 \mathrm{ppm})$, respectively and the mean $\mathrm{CH}_{2} \mathrm{O}$ concentration in $\mathrm{Ml}$ is less than 0.01 ppm. The mean $\mathrm{CH}_{2} \mathrm{O}$ concentrations in $\mathrm{M} 1, \mathrm{M} 2$ and $\mathrm{M} 3$ did not exceed the acceptable guideline limit of 0.1 ppm recommended by ICOP. The possible sources of indoor $\mathrm{CH}_{2} \mathrm{O}$ are wood-based materials, flooring materials, insulation materials, coating materials, indoor chemistry and indoor combustion; the disclosure of indoor $\mathrm{CH}_{2} \mathrm{O}$ is expected to be higher than the outdoor value (Salthammer et al., 2010). $\mathrm{CH}_{2} \mathrm{O}$ concentrations could exert adverse health effects on humans. Therefore, these concentrations also need to be monitored in indoor environments.

Table 4 shows that the highest mean PM concentrations $\left(\mathrm{PM}_{1}, \mathrm{PM}_{2.5}\right.$ and $\mathrm{PM}_{5}$ ) were in $\mathrm{M1}$, followed by $\mathrm{M} 3$ and $M 2$. The mean $P M_{1}$ concentrations in $M 1, M 3$ and $\mathrm{M} 2$ were $0.42 \pm 0.07 \mu \mathrm{g} / \mathrm{m}^{3}$ (range: $0.30-0.56 \mu \mathrm{g} / \mathrm{m}^{3}$ ), $0.33 \pm 0.03 \mu \mathrm{g} / \mathrm{m}^{3}$ (range: $0.25-0.39 \mu \mathrm{g} / \mathrm{m}^{3}$ ) and $0.24 \pm 0.03 \mu \mathrm{g} / \mathrm{m}^{3}$ (range: $0.21-0.30 \mu \mathrm{g} / \mathrm{m}^{3}$ ), respectively. For $\mathrm{PM}_{2.5}$, the mean concentrations in $\mathrm{M} 1, \mathrm{M} 3$ and $\mathrm{M} 2$ were $4.15 \pm 0.58 \mu \mathrm{g} / \mathrm{m}^{3}$ (range: $3.26-5.04 \mu \mathrm{g} / \mathrm{m}^{3}$ ), $3.55 \pm 0.34 \mu \mathrm{g} / \mathrm{m}^{3}$ (range: $2.91-4.21 \mu \mathrm{g} / \mathrm{m}^{3}$ ) and $2.90 \pm 0.42 \mu \mathrm{g} / \mathrm{m}^{3}$ (range: $2.39-3.69 \mu \mathrm{g} / \mathrm{m}^{3}$ ), respectively. Meanwhile, the mean $\mathrm{PM}_{5}$ concentrations in $M 1, M 3$ and $M 2$ were $12.54 \pm 2.79 \mu \mathrm{g} / \mathrm{m}^{3}$ (range: $9.60-17.50 \mu \mathrm{g} / \mathrm{m}^{3}$ ), $11.93 \pm 1.05$ $\mathrm{\mu g} / \mathrm{m}^{3}$ (range: $10.22-13.99 \mu \mathrm{g} / \mathrm{m}^{3}$ ) and $11.84 \pm 2.85 \mu \mathrm{g} / \mathrm{m}^{3}$ (range: $8.98-17.18 \mu \mathrm{g} / \mathrm{m}^{3}$ ), respectively. The highest mean $\mathrm{PM}_{10}$ concentration was in $\mathrm{M} 2\left(25.45 \pm 8.52 \mu \mathrm{g} / \mathrm{m}^{3}\right.$; range: 15.18-41.13 $\left.\mu \mathrm{g} / \mathrm{m}^{3}\right)$ followed by $\mathrm{Ml}$ (20.82 $\pm 5.21 \mu \mathrm{g} / \mathrm{m}^{3}$; range: $15.51-31.81$ $\left.\mu \mathrm{g} / \mathrm{m}^{3}\right)$ and $\mathrm{M} 3\left(16.54 \pm 1.05 \mu \mathrm{g} / \mathrm{m}^{3}\right.$; range: 14.79-18.27 $\left.\mathrm{\mu g} / \mathrm{m}^{3}\right)$. However, the mean $\mathrm{PM}_{1}, \mathrm{PM}_{2.5}, \mathrm{PM}_{5}$ and $\mathrm{PM}_{10}$ concentrations in M1, M2 and $\mathrm{M} 3$ still did not exceed the acceptable limit of $150 \mu \mathrm{g} / \mathrm{m}^{3}$ recommended by ICOP.

$P M$ is a common indoor pollutant and may cause adverse health effects. These health effects vary from minor respiratory symptoms to increments in morbidity and mortality rates depending on the exposure duration and pollutant concentration (Jedrychowski et al., 2013). The sources of PM inside mosques could be particles resuspended from carpets, infiltration of outdoor particles into the buildings as jemaah or congregators walk inside the mosques and secondary particle formation from the reaction of gaseous pollutants. Thatcher and Layton (1995), Ferro, Kopperud and Hildemann (2004) and Fromme et al. (2007) concluded in their studies that resuspension is a function of particle size, occupants' activities and types of floor materials.

Table 5 shows that the highest mean $\mathrm{CO}_{2}$ concentration was in $\mathrm{M} 2$, in which jemaah perform the Friday prayer. Their concurrent attendance during Dhuhr time on Fridays increased the number of people in the mosque and therefore contributed to a high $\mathrm{CO}_{2}$ concentration at this time. The maximum $\mathrm{CO}_{2}$ concentration in $\mathrm{M} 2$ reached $872 \mathrm{ppm}$, which is almost twice the maximum concentration values in $\mathrm{MI}$ and M3 (491 and 453 ppm, respectively) but still within the acceptable limit of 1,000 ppm. Reduced ventilation (Ahmed, Rahman and Shahrani, 2004), high number of jemaah and the level of activities of jemaah (Al-Dabbous et al., 2013) might affect $\mathrm{CO}_{2}$ levels in mosques during this time. The mean $\mathrm{CO}_{2}$ concentration in $\mathrm{M} 2$ was $526.25 \pm 82.37 \mathrm{ppm}$ (range: 447-872 ppm), followed by M1 and M3 with $455.82 \pm$ 11.69 ppm (range: $425-491$ ppm) and $413.04 \pm 11.98$ ppm (range: $397-453$ ppm), respectively. 
Table 4. Descriptive Statistics of the Respirable Particulate Matter Concentrations

\begin{tabular}{|c|c|c|c|c|}
\hline Mosque & M1 & M2 & M3 & Acceptable Limi \\
\hline \multicolumn{4}{|c|}{$\mathrm{PM}_{1}$ concentrations $\left(\mu \mathrm{g} / \mathrm{m}^{3}\right)$} & $150 \mu \mathrm{g} / \mathrm{m}^{3}$ \\
\hline$N$ total & 300 & 300.00 & 300 & \\
\hline Mean \pm SD & $0.42 \pm 0.07$ & $0.24 \pm 0.03$ & $0.33 \pm 0.03$ & \\
\hline Minimum & 0.3 & 0.21 & 0.25 & \\
\hline Median & 0.42 & 0.22 & 0.32 & \\
\hline Maximum & 0.56 & 0.30 & 0.39 & \\
\hline \multicolumn{4}{|c|}{$\mathrm{PM}_{2.5}$ concentrations $\left(\mu \mathrm{g} / \mathrm{m}^{3}\right)$} & $150 \mu \mathrm{g} / \mathrm{m}^{3}$ \\
\hline$N$ total & 300 & 300 & 300 & \\
\hline Mean \pm SD & $4.15 \pm 0.58$ & $2.90 \pm 0.42$ & $3.55 \pm 0.34$ & \\
\hline Minimum & 3.26 & 2.39 & 2.91 & \\
\hline Median & 3.98 & 2.74 & 3.435 & \\
\hline Maximum & 5.04 & 3.69 & 4.21 & \\
\hline \multicolumn{4}{|c|}{$\mathrm{PM}_{5}$ concentrations $\left(\mu \mathrm{g} / \mathrm{m}^{3}\right)$} & $150 \mu \mathrm{g} / \mathrm{m}^{3}$ \\
\hline$N$ total & 300 & 300 & 300 & \\
\hline Mean \pm SD & $12.54 \pm 2.79$ & $11.84 \pm 2.85$ & $11.93 \pm 1.05$ & \\
\hline Minimum & 9.6 & 8.98 & 10.22 & \\
\hline Median & 11.05 & 10.4 & 11.49 & \\
\hline Maximum & 17.5 & 17.18 & 13.99 & \\
\hline \multicolumn{4}{|c|}{$\mathrm{PM}_{10}$ concentrations $\left(\mathrm{\mu g} / \mathrm{m}^{3}\right)$} & $150 \mu \mathrm{g} / \mathrm{m}^{3}$ \\
\hline$N$ total & 300 & 300 & 300 & \\
\hline Mean \pm SD & $20.82 \pm 5.21$ & $25.45 \pm 8.52$ & $16.54 \pm 1.05$ & \\
\hline Minimum & 15.51 & 15.18 & 14.79 & \\
\hline Median & 18.26 & 22.015 & 16.665 & \\
\hline Maximum & 31.81 & 41.13 & 18.27 & \\
\hline
\end{tabular}

Table 5. Descriptive Statistics of the Ventilation Performance Indicator Concentrations

\begin{tabular}{lcccc}
\hline Mosque & M1 & M2 & M3 & Acceptable Limit \\
\hline $\mathrm{CO}_{2}$ concentrations & $(\mathrm{ppm})$ & & & \\
$\mathrm{N}$ total & 300 & 300 & 300 & \\
Mean $\pm \mathrm{SD}$ & $455.82 \pm 11.69$ & $526.25 \pm 82.37$ & $413.04 \pm 11.98$ & $1,000 \mathrm{ppm}$ \\
Minimum & 425 & 447 & 397 & \\
Median & 457.5 & 492 & 409 & \\
Maximum & 491 & 872 & 453 & \\
\hline
\end{tabular}


According to Lin and Deng (2003), the indoor $\mathrm{CO}_{2}$ level is one of the common indicators used to measure IAQ. The large number of jemaah during the Friday prayer increases the $\mathrm{CO}_{2}$ concentrations compared with those on normal days. Thus, the ventilation rate and sources of fresh air inside mosques are important factors that need to be considered. According to Mumovic et al. (2009) and Ponsoni and Raddi (2010), $\mathrm{CO}_{2}$ levels inside a building can be controlled by increasing the ventilation rate and sources of fresh air. The high $\mathrm{CO}_{2}$ level during the Friday prayer must be monitored because it could exert adverse effects on human health. Guais et al. (2011) mentioned that $\mathrm{CO}_{2}$ concentrations around or above 1,000 ppm, especially those above 10,000 ppm, are classified as toxicity values.

\section{CONCLUSIONS}

This study showed that the mean concentrations of nine indoor air contaminants (TVOC, $\mathrm{O}_{3}, \mathrm{CO}, \mathrm{CH}_{2} \mathrm{O}, \mathrm{PM}_{1}, \mathrm{PM}_{2.5}, \mathrm{PM}_{5}, \mathrm{PM}_{10}$ and $\mathrm{CO}_{2}$ ) in $\mathrm{Ml}$ (a historic mosque; monitored during Dhuhr to Asr payers) and $M 2$ (a historic mosque, monitored during Friday to Asr prayers) were still within the acceptable guideline limit recommended by ICOP. However, one of the nine parameters, which is mean $\mathrm{O}_{3}$ concentration in M3 (a floating mosque; monitored during Dhuhr to Asr prayers), exceeded the acceptable guideline limit. The mean $\mathrm{O}_{3}$ concentration in $\mathrm{M} 3$ exceeded the acceptable limit at 0.150 ppm because $M 3$ is located in a coastal and marine area. The $\mathrm{CO}_{2}$ level during the Friday prayer in $\mathrm{M} 2$ reached $872 \mathrm{ppm}$, which is close to the acceptable limit of 1,000 ppm recommended by ICOP. This result might be due to reduced ventilation conditions, large number of jemaah and their activities in the mosque. In conclusion, the concentration levels of indoor air contaminants in the prayer halls of the studied mosques in Malacca are in compliance with Malaysia's ICOP and DOSH (2010) and this compliance needs to be sustained to prevent any possible health effects on worshippers during their religious congregations and other activities. Providing adequate ventilation is a means to maintain good IAQ in the mosques. Nevertheless, a non-compliance issue for ozone was observed in one of the mosques due to its location.

\section{ACKNOWLEDGEMENTS}

This research was supported by the Ministry of Science Technology and Innovation Malaysia under the SCIENCEFUND 1001/PAWAM/6013607 (06-01-05-SF0766) grant and Jabatan Agama Islam Melaka.

\section{REFERENCES}

Abdullah, F.H., Majid, N.H.A. and Othman, R. (2016). Defining issue of thermal comfort control through urban mosque façade design. Proceedings: Social and Behavioral Sciences, 234: 416-423. https://doi.org/10.1016/j. sbspro.2016.10.259. 
Ahmed, A.Z., Rahman, S.A. and Shahrani, S. (2004). CO and $\mathrm{CO}_{2}$ concentrations in naturally-ventilated houses in Malaysia. Paper presented at the PLEA2004: The 21 st Conference on Passive and Low Energy Architecture. Eindhoven, The Netherlands, 19-22 September.

Al-Dabbous, A.N., Khan, A.R., Al-Rashidi, M.S. and Awadi, L. (2013). Carbon dioxide and volatile organic compounds levels in mosque in hot arid climate. Indoor and Built Environment, 22(2): 456-464. https://doi.org/10.1177/ $1420326 \times 12441807$.

Amin, N.D.M., Akasah, Z.A. and Razzaly, W. (2015). Architectural evaluation of thermal comfort: Sick building syndrome symptoms in engineering education laboratories. Proceedia - Social and Behavioral Sciences, 204: 19-28. https://doi.org/10.1016/j.sbspro.2015.08.105.

Awang, N.R., Ramli, N.A., Shith, S., Zainordin, N.S. and Manogaran, H. (2018). Transformational characteristics of ground level ozone during high particulate events in urban areas of Malaysia. Air Quality, Atmosphere and Health, 11: 715-727. https://doi.org/10.1007/s1 1869-018-0578-0.

Department of Occupational Safety and Health (DOSH) (2010). Malaysia's Industrial Code of Practice on Indoor Air Quality. Putrajaya: DOSH, Ministry of Human Resources.

Elbayoumi, M., Ramli, N.A., Md Yusof, N.F.F., Yahaya, A.S., Al Madhoun, W. and UISaufie, A.Z. (2014). Multivariate methods for indoor $\mathrm{PM}_{10}$ and $\mathrm{PM}_{2.5}$ modelling in naturally ventilated school buildings. Atmospheric Environment, 94: 11-21. https://doi.org/10.1016/j.atmosenv.2014.05.007.

Environmental Protection Agency (EPA) (2012). An Introduction to Indoor Air Quality (IAQ): Volatile Organic Compounds (VOCS). Washington DC: EPA. Available at: http://www.epa.gov/iaq/voc.html [Accessed on 5 March 2016].

Evans, K.A., Halterman, J.S., Hopke, P.K., Fagnano, M. and Rich, D.Q. (2014). Increased ultrafine particles and carbon monoxide concentrations are associated with asthma exacerbation among urban children. Environmental Research, 129: 11-19. https://doi.org/10.1016/j.envres.2013.12.001.

Fernández, L.C., Alvarez, R.F., Francisco Javier González-Barcala, F.J. and Portal, J.A.R. (2013). Indoor air contaminants and their impact on respiratory pathologies. Archivos de Bronconeumología, 49(1): 22-27. https://doi. org/10.1016/j.arbr.2012.11.004.

Ferro, A.R., Kopperud, R.J. and Hildemann, L.M. (2004). Source strengths for indoor human activities that resuspend particulate matter. Environmental Science and Technology, 38(6): 1759-1764. https://doi.org/10.1021/es0263893.

Fromme, H., Twardella, D., Dietrich, S., Heitmann, D., Schierl, R., Liebl, B. and Rüden, H. (2007). Particulate matter in the indoor air of classrooms: Exploratory results from Munich and surrounding area. Atmospheric Environment, 41 (4): 854-866. https://doi.org/10.1016/j.atmosenv.2006.08.053.

Guais, A., Brand, G., Jacquot, L., Karrer, M., Dukan, S., Grévillot, G., Molina, T.J., Bonte, J., Regnier, M. and Schwartz, L. (2011). Toxicity of carbon dioxide: A review. Chemical Research in Toxicology, 24(12): 2061-2070. https://doi. org/10.1021/tx200220r.

Hameed, A.A. and Habeeballah, T. (2013). Air microbial contamination at the holy mosque, Makkah, Saudi Arabia. Current World Environment, 2(8): 179-187. https://doi.org/10.12944/CWE.8.2.03. 
Jedrychowski, W.A., Perera, F.P., Spengler, J.D., Mroz, E., Stigter, L., Flak, E. and Jacek, R. (2013). Intrauterine exposure to fine particulate matter as a risk factor for increased susceptibility to acute broncho-pulmonary infections in early childhood. International Journal of Hygiene and Environmental Health, 216(4): 395-401. https://doi.org/10.1016/j.ijheh.2012.12.014.

Jo, W.J. and Sohn, J.Y. (2009). The effect of environmental and structural factors on indoor air quality of apartments in Korea. Building and Environment, 44(9): 1794-1802. https://doi.org/10.1016/j.buildenv.2008.12.003.

Jokl, M.V. (2000). Evaluation of indoor air quality using the decibel concept based on carbon dioxide and TVOC. Building and Environment, 35(8): 677-697. https://doi.org/10.1016/S0360-1323(99)00042-6.

Lee, S.C. and Chang, M. (2000). Indoor and outdoor air quality investigation at schools in Hong Kong. Chemosphere, 41(1-2): 109-113. https://doi. org/10.1016/S0045-6535(99)00396-3.

Lin, M., Horowitz, L.W., Cooper, O.R., Tarasick, D., Conley, S., Iraci, L.T. and Yates, E.L. (2015). Revisiting the evidence of increasing springtime ozone mixing ratios in the free troposphere over western North America. Geophysical Research Letters, 42(20): 8719-8728. https://doi.org/10.1002/2015GL065311.

Lin, Z. and Deng, S. (2003). The outdoor air ventilation rate in high-rise residences employing room air conditioners. Building and Environment, 38(12): 13891399. https://doi.org/10.1016/j.buildenv.2003.07.001.

Malaysian Standard (MS) (2014). MS 2577:2014 Architecture and Asset Management of Masjid: Code of Practice. Kuala Lumpur: Department of Standards Malaysia.

McKendry, I.G. and Lundgren, J. (2000). Tropospheric layering of ozone in regions of urbanized complex and/or coastal terrain: A review. Progress in Physical Geography, 24(3): 329-354. https://doi.org/10.1191/030913300701542660.

Mumovic, D., Palmer, J., Davies, M., Orme, M., Ridley, I., Oreszczyn, T. and Pearson, C. (2009). Winter indoor air quality, thermal comfort and acoustic performance of newly built secondary schools in England. Building and Environment, 44(7): 1466-1477. https://doi.org/10.1016/j.buildenv.2008.06.014.

Ocak, Y., Kilıçvuran, A., Eren, A.B., Sofuoglu, A. and Sofuoglu, S.C. (2012). Exposure to particulate matter in a mosque. Atmospheric Environment, 56: 169-176. https://doi.org/10.1016/j.atmosenv.2012.04.007.

Ponsoni, K. and Raddi, M.S.G. (2010). Indoor air quality related to occupancy at an air-conditioned public building. Brazilian Archives of Biology and Technology, 53(1): 99-103. https://doi.org/10.1590/S1516-89132010000100013.

Prihatmanti, R. and Bahauddin, A. (2014). Indoor air quality in adaptively reused heritage buildings at a UNESCO World Heritage Site, Penang, Malaysia. Journal of Construction in Developing Countries, 19(1): 69-91.

Ryoo, J.M., Johnson, M.S., Iraci, L.T., Yates, E.L. and Gore, W. (2017). Investigating sources of ozone over California using AJAX airborne measurements and models: Assessing the contribution from long-range transport. Atmospheric Environment, 155: 53-67. https://doi.org/10.1016/j.atmosenv.2017.02.008.

Salthammer, T., Mentese, S. and Marutzky, R. (2010). Formaldehyde in the indoor environment. Chemical Reviews, 110(4): 2536-2572. https://doi.org/10.1021/ cr800399g. 
Shan, X., Zhou, J., Chang, V.W.C. and Yang, E.H. (2016). Comparing mixing and displacement ventilation in tutorial rooms: Students' thermal comfort, sick building syndromes and short-term performance. Building and Environment, 102: 128-137. https://doi.org/10.1016/j.buildenv.2016.03.025.

Thatcher, T.L. and Layton, D.W. (1995). Deposition, resuspension and penetration of particles within a residence. Atmospheric Environment, 29(13): 1487-1497. https://doi.org/10.1016/1352-2310(95)00016-R.

Tong, L., Zhang, J., Xiao, H., Cai, Q., Huang, Z., Zhang, H. and Qian, F. (2017). Identification of the potential regions contributing to ozone at a coastal site of eastern China with air mass typology. Atmospheric Pollution Research, 8(6): 1044-1057. https://doi.org/10.1016/j.apr.2017.04.005.

Yahaya, N.Z., Ghazali, N.A., Ahmad, S., Mohammad Asri, M.A., Ibrahim, Z.F. and Ramli, N.A. (2017). Analysis of daytime and nighttime ground level ozone concentrations using Boosted regression tree technique. Environment Asia, 10(1): 118-129. 